\title{
KLAUZULA SUMIENIA LEKARZY A TRUDNY PRZYPADEK PRAWA
}

\begin{abstract}
Streszczenie. Celem tekstu jest próba opisania sytuacji odwołania się przez lekarza do klauzuli sumienia jako trudnego przypadku prawa w rozumieniu Ronalda Dworkina. Tak samo, jak ma to miejsce w trudnym przypadku, klauzula sumienia pozwala lekarzom odwołać się do autonomicznego systemu norm w przypadku niesprawiedliwego wyniku interpretacji norm systemu prawnego. Dzieje się tak dlatego, że sytuacja lekarza jest indywidualna i konkretna, w odróżnieniu od przepisów prawa, co każe uznać klauzulę nie za przyczynę zaistnienia trudnego przypadku, lecz drogę do jego rozwiązania. Ponadto instytucja klauzuli sumienia nakłada na lekarza dodatkowe obowiązki, które motywowane są zasadami prawa, poddanymi procesowi ważenia. Obecna w koncepcji Dworkina postawa interpretacyjna pozwala na rozszerzenie kategorii trudnego przypadku na sprawy niesądowe oraz nierozstrzygane przez sędziów.
\end{abstract}

Slowa kluczowe: sumienie w prawie, klauzula sumienia, klauzula sumienia lekarzy, trudny przypadek prawa, pozycja interpretacyjna.

\section{WPROWADZENIE}

Klauzula sumienia lekarzy jest jedną z nielicznych obecnych w polskim systemie prawnym instytucji stworzonych $\mathrm{w}$ celu obrony wolności sumienia. Wzbudza ona wiele kontrowersji, rozważanych również na wokandzie Trybunału Konstytucyjnego (orzeczenie TK z 7 października 2015 r., K 12/14, OTK 2015, nr 9A, poz. 143). Jednak na model działania, jaki wyznacza klauzula, można spojrzeć również z innej, niż powyższa, perspektywy. Sytuacja, w której lekarz może powołać się na klauzulę sumienia, może bowiem budzić skojarzenia z trudnym przypadkiem prawa. Główne podobieństwa i różnice pomiędzy klauzulą sumienia a trudnym przypadkiem prawa są właśnie przedmiotem tego tekstu.

Obecne unormowania ustawy regulującej wykonywanie zawodu lekarza pozwalają mu na odmówienie wykonania zabiegu z kilku powodów, w tym z powodu niezgodności konkretnego zabiegu z sumieniem lekarza. Regulacja taka pozwala na uchronienie lekarza od krzywdzącej wykładni generalnych i abstrakcyjnych norm oraz dostrzec jego indywidualną i konkretną sytuację w relacji z pacjentem.

Model ten ma szereg podobieństw z konstrukcją trudnego przypadku prawa, takich jak: możliwość pozaprawnego odwołania się do sumienia w regulowanej

\footnotetext{
*Uniwersytet im. Adama Mickiewicza w Poznaniu, rzymkowska.katarzyna@gmail.com.
} 
prawnie sytuacji zawodowej lekarza, możliwość wiążącego uznania przez lekarza norm określających obowiązki lekarza za naruszające jego sumienie, związane z klauzulą lekarskie obowiązki, w których dostrzec można ważenie racji i możliwość uwzględnienia więcej niż jednej zasady prawa, a także pozaprawny system wartości, do którego odwołuje się sumienie. Klauzulę odróżnia jednak od trudnego przypadku również szereg odmienności, przede wszystkim działanie pozasądowe oraz dokonywane przez innego adresata norm niż sędzia. Różnice te jednak - pomimo wspomnianej powyżej, którą można uznać za fundamentalną - wciąż pozwalają określić klauzulę sumienia lekarzy jako trudny przypadek prawa.

Spośród opisywanych w literaturze modeli rozumienia trudnego przypadku klauzula sumienia wykazuje najwięcej podobieństw do ujęcia Ronalda Dworkina, dla którego trudny przypadek jest właśnie konfliktem norm prawnych i moralnych, z którymi lekarz ma przecież do czynienia, gdy może zastosować instytucję klauzuli sumienia. Ponadto Dworkin rozwiązania trudnego przypadku nie opiera na swobodnym uznaniu czy otwartej tekstualności prawa, lecz na instytucjach samego prawa - podobnie jak w przypadku klauzuli, której istnienie, granice i uzasadnienie kształtuje ustawodawca. Dlatego niniejszy tekst będzie opierał się wyłącznie na jego rozumieniu trudnego przypadku.

Wpisanie instytucji klauzuli sumienia lekarzy w ramy trudnego przypadku prawa pozwala nie tylko spojrzeć z innej perspektywy na obecny stan prawny regulujący tę kwestię, lecz także dostrzec rolę tego typu instytucji w prawie w ogólności i - wychodząc od tego wzoru - dokonywać poprawy istniejących regulacji czy kreować nowe.

\section{KLAUZULA SUMIENIA A TRUDNY PRZYPADEK - DEFINICJE}

Rozważania na temat samej instytucji klauzuli sumienia w prawie należy rozpocząć od przytoczenia treści przepisu ją regulującego. Artykuł 39 ustawy o zawodzie lekarza i lekarza dentysty wprowadza możliwość odmowy wykonania zabiegu leczniczego niezgodnego z sumieniem lekarza. Przepis wskazuje również związane z odmową obowiązki (poinformowanie przełożonego oraz wpisanie odmowy do dokumentacji medycznej), stanowiąc tym samym wzór rozwiązania kolizji norm wnioskowanych z sumienia lekarzy z normami wynikającymi z przepisów ustawy, wymagających od lekarza udzielenia pomocy pacjentowi. Pokazuje tym samym płaszczyznę, na jakiej może pojawiać się trudny przypadek (w omawianej sytuacji jest to sumienie lekarza oraz normy nakazujące wykonywanie zabiegów) oraz nadaje reguły rozwiązania sporu.

W tym miejscu należy przywołać definicję trudnego przypadku. Uznaje się za niego sprawę, w której proste zastosowanie reguły prowadziłoby do popełnienia niesprawiedliwości (Izdebski 2011, 172). Jak zauważa Tadeusz Biernat, powstaje on przez to, że istnieje 
pewien charakterystyczny mechanizm, który występuje zarówno w procesie stosowania prawa, interpretacji prawa, jak i tworzenia prawa. To zjawisko można opisać jako standardowe, zrutynizowane, mechaniczne działanie prowadzące do uzyskania zamierzonych efektów. [...] Sprawa złożona, skomplikowana, wymagająca większego nakładu pracy i zaangażowania jest tylko pozornie trudna, jeśli standardowe metody pozwalają na jej rozwiązanie. Niewydolność, zacięcie się tego mechanizmu może być spowodowane różnymi okolicznościami, a ich pojawienie się sprawia, że mamy do czynienia z trudnym przypadkiem (Biernat 2010, 476-477).

Jednak klasyczne rozumienie trudnego przypadku zakłada jego zaistnienie wyłącznie w ramach sprawy sądowej oraz wyłącznie w procesie wykładni norm przez sędziego. Takie rozumienie zakłada dwa przymioty trudnego przypadku. Po pierwsze, musi być on „sądowy”, po drugie zaś - „sędziowski”. Model ten, tak mocno oparty na amerykańskim procesie stosowania prawa, zdaniem niektórych autorów w ogóle nie jest możliwy do przełożenia na kontynentalny system prawa. I tak na przykład, zdaniem Jana Woleńskiego „kategoria sprawy trudnej jest charakterystyczna dla systemu prawa opartego na precedensach i nie ma dokładnego odpowiednika w ramach kontynentalnego systemu prawa" (Woleński 1998, XV). Według innych ewentualna analogia mogłaby mieć miejsce, jednak tylko na płaszczyźnie stosowania prawa (Zajadło 2013, 382) - niezmieniony pozostałby zatem ,sądowy” (w szerokim rozumieniu) przymiot trudnego przypadku.

\section{KLAUZULA SUMIENIA A TRUDNY PRZYPADEK - PODOBIEŃSTWA}

Możliwe jest jednak uznanie klauzuli sumienia lekarzy za trudny przypadek zarówno niesędziowski, jak i niesądowy. Pozwalają na to istniejące, kluczowe dla rozumienia trudnego przypadku podobieństwa, które dostrzec można na kilku płaszczyznach: w pierwszej kolejności w możliwości pozaprawnego odwołania się do sumienia w sytuacji zawodowej lekarza, czyli regulowanej normami prawnymi. Następnie, odwołanie to jest możliwe jedynie w przypadku uznania wyniku wykładni norm określających obowiązki lekarza za naruszające jego sumienie i naruszające tym samym jego godność, co także należy uznać za podobieństwo z trudnym przypadkiem. Kolejno, sprzężone przez wyrażenie lekarskich obowiązków ważenie racji i możliwość uwzględnienia więcej niż jednej zasady prawa również powinno budzić skojarzenia $\mathrm{z}$ trudnym przypadkiem. I wreszcie, system wartości, do którego odwołuje się sumienie, wywoływany jest tym samym działaniem lekarza, co odwołanie się do systemu prawnego; tym samym odwołanie się do systemu prawa musi pobudzić akt, którym jest sumienie.

Rozpoczynając od pierwszego podobieństwa (możliwości pozaprawnego odwołania się do sumienia w sytuacji zawodowej lekarza), art. 39 ustawy z 5 grudnia 1996 r. o zawodach lekarza i lekarza dentysty wprost wskazuje, że lekarz „może powstrzymać się od wykonania świadczeń niezgodnych z jego sumieniem” (Dz. U. 1997, Nr 28, poz. 152). W sytuacji kolizji norm wnioskowanych 
z sumienia z normami wynikającymi z przepisów ustawy, ta ostatnia pozwala odwołać się do standardów - z punktu widzenia przepisu - pozaprawnych. Analizując artykuł można dostrzec wyraźnie, iż lekarz nie dość że może odwołać się do własnego, autonomicznego systemu norm, z którym zgodność ocenić ma indywidualny akt sumienia, to jeszcze może zadziałać zgodnie z tym właśnie systemem i na jego płaszczyźnie znaleźć motywację dla swojego działania.

Sumienie jako źródło działań lekarza nie jest ujmowane w ustawie jako część światopoglądu oraz jest w stanie wpływać na lekarza niezależnie od wyznania. Należy zatem odrzucić wszelkie argumenty dotyczące religijnych podstaw przepisów o klauzuli sumienia - jej istnienie nie stanowi bowiem przywileju dla osób wierzących, a obowiązek umotywowania decyzji odmową sumienia w dokumentacji medycznej nie zmusza osób religijnych do ujawniania swojego wyznania.

W kwestii drugiego podobieństwa (odwołanie możliwe jedynie w przypadku uznania wyniku wykładni norm określających obowiązki lekarza za naruszające jego sumienie) należy zauważyć, że art. 39 ustawy reguluje zwolnienie lekarza z obowiązku wyłącznie z powodu niezgodności zabiegu z jego sumieniem. Ustawodawca wśród obowiązków lekarza, który zdecyduje się odmówić wykonania zabiegu, wymienia m.in. wpisanie odmowy i uzasadnienia swojej decyzji do dokumentacji medycznej. Wydaje się, że właśnie to ostatnie zadanie stanowić ma narzędzie przymuszające lekarzy do rozważenia dotkliwej niezgodności zabiegu $\mathrm{z}$ ich sumieniem.

Podobieństwo do trudnego przypadku przejawia się tutaj właśnie poprzez dostrzeżenie konsekwencji prostej subsumpcji norm generalnych i abstrakcyjnych $\mathrm{w}$ indywidualnym i konkretnym przypadku. Normy dotyczące wykonywania przewidzianych przez system opieki zdrowotnej zabiegów nie rodzą przecież na pierwszy rzut oka wątpliwości, które mogłyby stanowić podstawę trudnego przypadku. Szczególnie, że należy cały czas pamiętać o obecnej w naturze zawodu lekarza relacji z pacjentem, któremu normy te mają zapewnić dostęp do opieki lekarskiej.

Jednak odnosząc obowiązek wykonywania wszystkich zabiegów, rozumiany generalnie i abstrakcyjnie, do konkretnego lekarza, to znaczy konkretnej osoby $\mathrm{z}$ autonomicznym systemem wartości, stosowanie norm wprost może $\mathrm{w}$ ten system uderzać, otwierając pole dla trudnego przypadku. Incydentalny charakter tego ostatniego przejawia się właśnie poprzez rozdźwięk pomiędzy normą prawną, która co do zasady jest generalna i abstrakcyjna, oraz przypadku, który poprzez osobę staje się indywidualny i konkretny, czyniąc sytuację jednorazową. Owa indywidualizacja i konkretyzacja, na którą pozwala klauzula sumienia, może prowadzić do różnych modeli działania, tym samym zaproponowanie jednego, do którego prowadzi przecież prosta subsumpcja norm, byłoby oczywiście krzywdzące.

Jeżeli chodzi o trzecie podobieństwo (sprzężone przez wyrażenie lekarskich obowiązków ważenie racji i możliwość uwzględnienia więcej niż jednej zasady prawa), najlepiej wyrażają je - wskazane w konstrukcji klauzuli sumienia - lekarskie obowiązki, którym należy w tym miejscu poświęcić więcej uwagi. 


\section{KLAUZULA SUMIENIA - OBOWIĄZKI LEKARZA}

Mechanizm zaproponowany przez klauzulę sumienia wpisuje się poprzez lekarskie obowiązki w teorię reguł i zasad Dworkina. Przenosząc rozważania na jej grunt, można by uznać podstawy aksjologiczne przepisu pozwalającego lekarzowi na działanie w zgodzie z własnym sumieniem oraz analogiczne podstawy dla przepisów uwzględniających prawa pacjenta za zasady. W momencie ich konfliktu aktualizują się obowiązki zawarte w przepisach określających klauzulę sumienia, która, moim zdaniem, może być uznana za regułę kolizyjną. Reguła ta musi być jednak inspirowana przez zasady. Jak bowiem słusznie wskazuje Marzena Kordela, reguła jest efektem „swoistego przełożenia [...] wartości na pewne zachowanie. Bowiem w ścisłym tego słowa znaczeniu stosować można jedynie regułę, a nie zasadę jako taką, gdyż pewność i obliczalność prawa wymagaja, aby adresat odpowiadał za zachowanie, a nie wartość" (Kordela 2012, 211).

Zdaniem Dworkina, ze względu na wymiar doniosłości zasad „w przypadkach, gdy zasady krzyżują się ze sobą [...], konflikty takie muszą być rozwiązywane przy uwzględnieniu względnej doniosłości każdej z nich" (Dworkin 1998, 64). Takie wpisane w naturę dworkinowskich zasad ich wyważenie bez wątpienia ma miejsce w przypadku klauzuli sumienia - właśnie wskazane w ustawie obowiązki wpisują się w mechanizm równoważenia. W tym miejscu należy przeanalizować wymienione zadania.

Do lekarzy pracujących w ramach stosunku pracy należy obowiązek poinformowania o odmowie w dwojaki sposób: poprzez wpisanie odmowy do dokumentacji medycznej oraz powiadomienie przełożonego. Oba działania spotykają się z niechęcią środowiska jako zmuszające do upublicznienia własnych przekonań religijnych. Jednak w mojej opinii od lekarza odmawiającego wykonania zabiegu wymaga się jedynie podania racji z sumienia, czyli ujawnienia, że to jego sumienie nie pozwala mu w takiej sytuacji działać. Nieważna dla ustawodawcy jest tutaj motywacja sumienia. Takie nakierowanie obowiązku, czyli wskazanie racji dla odmowy, budzi skojarzenia z argumentacją na rzecz ważności zasady u Dworkina. Jego zdaniem

nie jesteśmy w stanie udowodnić mocy czy doniosłości określonej zasady tak, jak możemy udowodnić ważność przepisu, lokalizując go w jakimś akcie kongresu lub opinii właściwego sądu. Zamiast tego, przedstawiamy argumenty przemawiające za zasadą i jej doniosłością, odwołując się do połączenia praktyki i innych zasad, w którym implikacje wynikające z historii instytucji legislatury i sądownictwa towarzyszą odwołaniom do społecznych praktyk i przekonań (Dworkin 1998, 81).

Z mojej perspektywy najbardziej doniosłe jest jednak ostatnie, ogólne podobieństwo klauzuli sumienia i trudnego przypadku prawa. Wskazuje ono na fakt, że system wartości, do którego odwołuje się lekarz poprzez swoje sumienie, nie motywuje działania o innym charakterze u tego ostatniego niż system norm 
prawnych, i tym samym odwołanie się do tego drugiego musi pobudzić indywidualny akt, którym jest sumienie.

Sednem trudnego przypadku jest bowiem odwołanie się do innych norm aniżeli normy prawne. Jak wskazuje Maciej Dybowski, ,jeśli bowiem brak regulacji normatywnej dla danego rozstrzygnięcia sędziowskiego - nie można więc zastosować prawa »mechanicznie«, dokonując subsumpcji - sędzia odwołuje się do jakichś innych wypowiedzi dyrektywalnych, np. do norm moralnych czy obyczajowych" (Dybowski 2001, 103-104).

Nie należy jednak utożsamiać wyjścia poza automatyczną wykładnię z pojęciami niedookreślonymi. Te ostatnie już właściwie na etapie tworzenia prawa zakładają zmuszenie interpretującego prawo do wyjścia poza mechaniczną jego wykładnię. Istotą trudnego przypadku jest zaś właśnie jego incydentalność, odejście od utartych ścieżek wykładni nie na poziomie generalnym i abstrakcyjnym, jak ma to miejsce w przypadku pojęć niedookreślonych, lecz ze względu na dostrzeżenie sytuacji indywidualnej i konkretnej, a w tej sytuacji - lekarza jako osoby, z systemem wartości i indywidualnym sumieniem. Tym samym należy przychylić się do krytyki postulowanych w literaturze propozycji stworzenia klauzuli sumienia zakładów leczniczych (na wzór rozwiązań amerykańskich) (Zielińska 2008, 560-561), dezawuujących traktowanie lekarza jako osoby. W tym miejscu należy przypomnieć, za Marzeną Kordelą, że

to, jakie ostatecznie zachowanie zostanie uznane za powinne ze względu na wartość objętą zakresem normowania zasady, zależy od konkretnych warunków badanego przypadku. Rysujące się niebezpieczeństwo arbitralności zostaje uchylone poprzez fakt, że system prawa jest tak konstruowany, aby klasa możliwych do wyboru elementów-zachowań miała ograniczony zakres (Kordela 2012, 211).

I tak jest też w przypadku klauzuli - klasa zachowań ograniczona jest treścią art. 30 ustawy oraz obowiązkami zawartymi w samej instytucji klauzuli.

Klauzulę sumienia odróżnia również od pojęć niedookreślonych jej rola w zaistnieniu i rozwiązaniu trudnego przypadku. Nie kreuje ona bowiem takiego przypadku, tak jak mogłyby to robić pojęcia niedookreślone (Wojciechowski 2004, 24), ale jest właśnie mechanizmem szukania rozwiązania danego przypadku.

Akt odwołania się do innych systemów norm, w tradycyjnych ujęciach trudnego przypadku, leży w ręku sędziego i ma miejsce dopiero na sali sądowej. Klauzula pozwala jednak na szukanie rozwiązania trudnego przypadku, pomijając te dwa przymioty. Jej niesędziowskie ujęcie stawia w tym miejscu lekarza, którego podmiotowość i godność ma być zagwarantowana poprzez istnienie klauzuli w systemie. Wzmaga je możliwość natychmiastowego jej użycia, tj. już w momencie odczucia, że zabieg, który lekarz ma wykonać, jest niezgodny z jego sumieniem. Nie musi on zatem czekać z powołaniem się na swój system wartości na sali sądowej, ale może to zrobić już w gabinecie, co nadaje klauzuli charakter niesądowego trudnego przypadku.

Dlaczego zatem, pomimo odrzucenia obu - wydawałoby się - niezbędnych przymiotów, klauzulę wciąż można nazywać trudnym przypadkiem prawa? Przy 
konstruowaniu odpowiedzi na to pytanie kluczowe jest odwołanie się do obecnej w koncepcji Dworkina postawy interpretacyjnej wobec prawa i, poprzez nia, dostrzeżenie natury prawa jako wytworu kultury oraz systemu podobnego do systemu wartości, do którego odwołuje się indywidualny akt sumienia.

\section{KLAUZULA SUMIENIA A POSTAWA INTERPRETACYJNA WOBEC PRAWA}

Odmienność i nieoczywista kwalifikacja (pomiędzy pozytywizmem i jusnaturalizmem) teorii Dworkina wynika m.in. z proponowanej przez niego postawy wobec prawa - postawy interpretacyjnej. Dworkin uznaje interpretację prawa za interpretację praktyki społecznej, która - podobnie jak interpretacja artystyczna - zmierza do „interpretowania czegoś, co zostało stworzone przez ludzi, jako rzeczy odrębnej od nich" (Dworkin 2006, 50). Nie zakłada on, śladem pozytywistów, w mocnym sensie, że prawo jest systemem nadanym. Jego rozumienie bliższe jest raczej uznania prawa za twór kulturowy, obiekt, który ze swojej natury musi podlegać interpretacji - nazywa je wprost „pojęciem interpretacyjnym” (Dworkin 2006, 411). Jak ujmuje to Marek Zirk-Sadowski: „Prawo nie jest opisywane jako coś danego i istniejącego obiektywnie, niezależnie od procesu interpretacji, ale też nie jest tworzone w trakcie wykładni" (Zirk-Sadowski 2006, XV).

Postawa interpretacyjna, nazywana też twórczą, charakteryzuje niemal każdą postawę wobec prawa - adresat normy musi przecież normę zinterpretować. Dopiero interpretacja normy pozwala na indywidualne odniesienie się do niej, a w konsekwencji - na zmianę (lub nie) swojego postępowania, czyli świadome realizowanie bądź naruszenie normy. Kto bowiem świadomie realizuje normę, to znaczy „co najmniej wie, że obowiązuje norma o takiej, a nie innej treści lub nawet - pod jej wpływem - modyfikuje swoje postepowanie" (Wronkowska 2005, 120). Odnoszacc się do omawianego przypadku, interpretacja pozwala lekarzowi zmienić swoje automatyczne, wyrażone przez prostą subsumpcję norm dotyczących wykonywania zabiegów, lekarskie działanie. W przypadku klauzuli można mówić jedynie o świadomym realizowaniu normy, bowiem sama treść tej instytucji wymaga działań o charakterze aktywnym (uzasadnienie sprzeciwu, powiadomienie przełożonego).

Moim zdaniem postawa interpretacyjna wobec prawa nie musi cechować wyłącznie sędziego (w wąskim rozumieniu trudnego przypadku) czy prawnika. Jest ona bowiem świadomym procesem intelektualnym, którego wspólnym elementem jest działanie poprzez rozum. Nie ulega wątpliwości, że proces taki jest dany nie tylko prawnikom, ale i innym adresatom norm - zdaniem Jerzego Zajadło za czynnik decydujący o tym, czy mamy do czynienia z trudnym przypadkiem, należy uznać „fakt wielości możliwych rozwiązań, które da się uzasadnić w procesie dyskursu praktycznego na gruncie przyjętych kryteriów racjonalności i słuszności”. Wówczas tak rozumiany trudny przypadek ,nie jest wyłącznie domeną 
sędziego poszukującego rozwiązania w konkretnej sprawie, w której nie ma do dyspozycji jednoznacznej reguły prawnej" (Zajadło 2008, 13). Co więcej, musi być on dostępny ze względu na powszechne podleganie normom systemu prawa - nie tylko przecież przez prawników.

Ta sama władza umysłowa (działanie rozumu), która jest odpowiedzialna za świadome realizowanie norm, odpowiedzialna jest również za sumienie. Sumienie rozumiem tutaj, za Maciejem Dybowskim, jako ,akt jednostkowy, generujący wnioski praktyczne indywidualne [...] i konkretne (dotyczące działania jednorazowego)" (Dybowski 2015, 96), którego dokonanie „możliwe jest w przypadku każdego" (tamże, 97), a którego wnioski praktyczne „muszą być uzasadnialne” (tamże). Samo zaś pojęcie „musi dopuszczać możliwość popełnienia błędu, a przy tym nie ma kryteriów, które umożliwiałyby dokonanie oceny i podważenie wniosku praktycznego [...] w akcie posługiwania się sumieniem" (tamże).

Ocena taka oparta jest na indywidualnym systemie wartości i dokonywana jest niezależnie od źródła działania, niejako automatycznie. Nie jest ona jednak dokonywana przy każdej czynności, lecz w momencie zwątpienia, wyczucia potrzeby dokonania takiej oceny. Jednocześnie jest ona na tyle wiążąca, że działanie wbrew niej wywołuje doniosłe skutki w sferze intymnej osoby.

Powyższa charakterystyka pozwala sformułować wniosek, że w naturze rozumu ludzkiego nie leży odmienne zachowanie przy interpretacji różnych systemów norm - ocena poprzez akt sumienia dokonuje się niejako zawsze dodatkowo, kiedy wykaże się taką potrzebę. Jeżeli potrzeba taka rodzi się w momencie wątpliwości, to prawo, które może budzić takie wątpliwości, będzie rodzić potrzebę, a ta ostatnia - akt i ocenę. Zignorowanie możliwości zaistnienia tego aktu jest zignorowaniem także konsekwencji, które rodzi ocena sprzeczna z założeniami prawodawcy - czyli albo nieposłuszeństwo prawu, albo uderzenie w godność ludzką. Wtórnie do tych konsekwencji mógłby pojawić się trudny przypadek, również zignorowany przez prawodawcę.

\section{NOWE TRUDNE PRZYPADKI - PERSPEKTYWA PRAWODAWCZA}

Poprzez opisane wynikanie działań sumienia można dostrzec, że prawodawca jest zdolny zauważyć i wychwycić te sytuacje, w których może zaistnieć trudny przypadek. O ile bowiem trudny przypadek może zrodzić się także z wadliwości redakcyjnych, o tyle przede wszystkim może on mieć miejsce wtedy, kiedy prawodawca nie popełnił żadnych błędów na etapie tworzenia prawa. Poza jednym: zignorowałby on osobowy aspekt adresatów normy, w omawianym przypadku lekarzy.

Tym samym odnalezienie trudnego przypadku jest możliwe już na poziomie tworzenia prawa, co pozwala również na tym samym poziomie nakierować na rozwiązanie. Jak wskazuje Tadeusz Biernat, 
Tak scharakteryzowanemu punktowi wyjścia [złej jakości obowiązującego prawa - przyp. K. Rz.] towarzyszy przekonanie, że w tym ważnym aspekcie refleksji nad prawem możliwe jest wskazanie obszaru badawczego i kierunków dyskusji naukowej, której efekty mogą się przyczynić do modyfikacji działań prawotwórczych i podniesienia jakości tworzonego prawa. Głównym obszarem tych badań powinno być określenie pola i organizacji dyskursu legislacyjnego. Analiza podstaw wyodrębnienia [...] ,trudnych spraw” [...] umożliwia wskazanie ważnych punktów dyskursu legislacyjnego (Biernat 2010, 474).

W przypadku takim, jak klauzula sumienia, wydaje się to wręcz konieczne ze względu na wartość konkurujących tutaj dóbr prawnych. Jeżeli bowiem problem nie zostanie rozwiązany przez prawodawcę na poziomie tworzenia prawa, przez ocenę uzyskaną w formie indywidualnego aktu, jakim jest sumienie, lekarz sam mógłby przecież dojść do własnego rozwiązania trudnego przypadku, jakim byłoby, jego zdaniem, wymuszenie dokonywania każdego zabiegu gwarantowanego w ramach systemu opieki zdrowotnej. Jeżeli działanie niezgodne z własnym systemem norm byłoby dla niego przesadnie dotkliwe (co już należałoby uznać za porażkę prawodawcy), uchyliłby się on po prostu od obowiązku, narażając się oczywiście przy tym na sankcję. Swoje działanie mógłby uznać za dążenie do zmiany prawa ocenionego przez niego negatywnie, przejawiając przy tym gotowość do dawania posłuchu lepszemu prawu.

W omawianym przypadku jednak zachowanie lekarza, ze względu na naturę jego zawodu, nawet jeżeli zostałoby ukarane dotkliwą sankcją mogłoby przedstawiać konsekwencje niezwykle poważne. W praktyce oznaczałoby przecież pozostawienie pacjenta bez opieki, co skutkować mogłoby nawet najdotkliwszymi dla tego ostatniego konsekwencjami. I choć lekarz zostałby najpewniej surowo ukarany, konsekwencji jego działania - z oczywistych powodów - nie można by już było odwrócić.

Dlatego właśnie uważny (na trudny przypadek) i szanujący lekarza (jako osobę) prawodawca rozwiązuje ten problem za niego, właśnie na poziomie tworzenia prawa. Takie rozwiązanie, wbrew sądom przeciwników istnienia klauzuli sumienia w systemie prawa, pozwala też na uszanowanie pacjenta, dostrzega bowiem wyjątkowość relacji lekarza z pacjentem.

Konstrukcja klauzuli pozwala ponadto uniknąć sytuacji w praktyce lekarskiej o konsekwencjach nie do odwrócenia - jest ona ograniczona wyjątkami z art. 30 tej samej ustawy. Brak klauzuli w systemie w oczywisty sposób nie pozwoliłby na jej wyłączenie na podstawie cytowanego artykułu.

\section{PODSUMOWANIE}

Podsumowując - wprowadzenie instytucji klauzuli sumienia w systemie prawa jest wyrazem uważności prawodawcy na etapie tworzenia prawa. Dostrzegł on możliwość zaistnienia trudnego przypadku, jakim byłoby zmuszenie lekarza - osoby z indywidualnym systemem wartości - do mechanicznego stosowania 
się do nakazu wykonywania świadczeń medycznych. Jednocześnie, unormowane wraz z klauzulą obowiązki lekarza zdecydowanego odmówić podjęcia się zabiegu są wyrazem ważenia zasad prawa będących w tej sytuacji w konflikcie - prawa lekarza do wolności sumienia i prawa pacjenta do opieki zdrowotnej.

Dostrzeżenie takich konsekwencji przez prawodawcę oraz wykreowanie równoważących uprawnienie lekarza, przewidzianych dla niego obowiązków, możliwe jest dzięki szerokiemu, niesądowemu i niesędziowskiemu rozumieniu trudnego przypadku, opartego na pojęciu osoby i sumienia jako aktu oceny, kreujących postawę interpretacyjną wobec prawa dostępną dla każdego adresata norm. Takie ujęcie instytucji związanych $\mathrm{z}$ ochroną sumienia $\mathrm{w}$ systemie prawnym pozwoli nakierować uwagę prawodawcy - już na etapie tworzenia prawa - także na inne, podobne instytucje i pozwoli, być może, uniknąć błędów i kontrowersji towarzyszących samej klauzuli.

Drogą do takiego nakierowania musi być z pewnością dostrzeganie nowych zasad prawa, które przecież „najbardziej skuteczne w działaniu i najbardziej doniosłe wydają się one [zasady - przyp. K. Rz.] jednak w trakcie trudnych procesów" (Dworkin 1998, 68). Mówię tutaj o dostrzeganiu, bowiem w ujęciu Dworkina w przypadku zasad za nieskuteczny należy uznać sprawdzian rodowodu. Jego zdaniem „zasady prawne, nie są [...] skutkiem jakiejś określonej decyzji organu ustawodawczego czy sądu, lecz wynikiem poczucia stosowności rozwiniętego z czasem wśród prawników oraz w szerokich kręgach społecznych" (Dworkin 1998, 87). Jeżeli takie poczucie stosowności będzie sukcesywnie rozwijane, prawdopodobnie nie unikniemy trudnych przypadków w procesie tworzenia czy stosowania prawa, ale wypracujemy lepsze narzędzia do ich rozwiązywania.

\section{BIBLIOGRAFIA}

Biernat, Tadeusz. 2010. „Trudne sprawy” w procesie tworzenia prawa. Pole dyskursu legislacyjnego. W W poszukiwaniu dobra wspólnego. Księa jubileuszowa profesora Macieja Zielińskiego. Red. Agnieszka Choduń, Stanisław Czepita. 473-489. Szczecin: Wydawnictwo Naukowe Uniwersytetu Szczecińskiego.

Dworkin, Ronald. 1998. Biorqc prawa poważnie. Tł. Tomasz Kowalski. Warszawa: Wydawnictwo Naukowe PWN.

Dworkin, Ronald. 2006. Imperium prawa. Tł. Jan Winczorek. Warszawa: Oficyna a Wolters Kluwer business.

Dybowski, Maciej. 2001. „Ronalda Dworkina koncepcja zasad prawa”. Ruch Prawniczy, Ekonomiczny $i$ Socjologiczny 63: 99-115.

Dybowski, Maciej. 2015. „Sumienie w klauzuli sumienia lekarzy”. W Maciej Dybowski, Marcin Romanowski. O trudnych przypadkach w filozofii prawa. 69-111. Warszawa: Wydawnictwo Uniwersytetu Kardynała Stefana Wyszyńskiego.

Izdebski, Hubert. 2011. Elementy teorii i filozofii prawa. Warszawa: LexisNexis.

Kordela, Marzena. 2012. Zasady prawa. Studium teoretycznoprawne. Poznań: Wydawnictwo Naukowe UAM. 
Stelmach Jerzy. 2010. „Trudny przypadek w prawie”. W W poszukiwaniu dobra wspólnego. Księga jubileuszowa profesora Macieja Zielińskiego. Red. Agnieszka Choduń, Stanisław Czepita. 141-150. Szczecin: Wydawnictwo Naukowe Uniwersytetu Szczecińskiego.

Wojciechowski, Bartosz. 2004. „Rozstrzyganie tzw. trudnych przypadków przez odwołanie się do odpowiedzialności moralnej”. Studia Prawno-Ekonomiczne 70: 9-26.

Woleński, Jan. 1998. „Wstęp”. W Ronald Dworkin. Biorqc prawa poważnie. Tł. Tomasz Kowalski. VII-XIX. Warszawa: Wydawnictwo Naukowe PWN.

Wronkowska, Sławomira. 2005. Podstawowe pojęcia prawa i prawoznawstwa. Poznań: Ars Boni et Aequi.

Zajadło, Jerzy. 2008. „Co to są hard cases?”. W Fascynujace ścieżki filozofii prawa. Red. Jerzy Zajadło. 7-19. Warszawa: Wydawnictwo Prawnicze LexisNexis.

Zajadło, Jerzy. 2013. „Czy istnieją i czym są hard cases?”. W Filozofia prawa w pytaniach i odpowiedziach. Red. Jerzy Zajadło, Kamil Zeidler. 379-388. Warszawa: LexisNexis.

Zielińska, Eleonora. 2008. Ustawa o zawodach lekarza i lekarza dentysty. Komentarz. Warszawa: $\mathrm{ABC}$ a Wolters Kluwer business.

Zirk-Sadowski, Marek. 2006. „Wprowadzenie”. W Ronald Dworkin. Imperium prawa. Tł. Jan Winczorek. XI-XXVI. Warszawa: Oficyna a Wolters Kluwer business.

\title{
Katarzyna Rzymkowska
}

\section{MEDICAL CONSCIENCE CLAUSE AND THE HARD CASE}

\begin{abstract}
The aim of the paper is to describe the situation of using the medical conscience clause as a hard case in Ronald Dworkin's understanding. Like in a hard case, the clause creates a possibility to appeal to an autonomous system of rules in case of an unjust result of interpretation of the rules of law. It is so because the doctor's situation is individual and specific in contrast to the rules of law. Moreover, the clause has to be seen as a way to resolve a hard case, not as its reason. Furthermore, the institution of the conscience clause imposes additional duties on doctors, which are motivated by judging legal principles against one another. Additionally, the Dworkin's interpretative attitude allows extending the category of hard cases to non-judicial cases and not adjudicated by judges.
\end{abstract}

Keywords: conscience in law, conscience clause, medical conscientious objection, hard case in law, interpretative attitude. 